\title{
TESTING THE PERFORMANCE OF AQUACROP MODEL FOR SUNFLOWER PRODUCTION IN THE MIDDLE OF IRAQ
}

\author{
Eman H.Sheet, Entesar M.Gazal ${ }^{*}$ and Maan H. Sheet ${ }^{* *}$ \\ *Dept. of Dams \& Water Resources, College of Engineering, University of Mosul-Iraq \\ College of Agriculture, University of Duhok, Kurdistan Region-Iraq
}

(Received: May 23, 2018; Accepted for Publication: January 21, 2019)

\begin{abstract}
AquaCrop is a reliable model for estimating crop productivity under rainfed or irrigation to improve water use efficiency in agriculture. The performance of AquaCrop was tested for sunflower. Field experiments were conducted during the seasons 2009 \& 2010 at experimental farm, College of agriculture, Abu Ghraib, Baghdad, Iraq. Yield and biomass were measured under different irrigation treatments and two row spacing 20 and $30 \mathrm{~cm}$. Input data and comparisons between simulated and observed yield production was done under different irrigation management conditions and row spacing. The model is calibrated with experimental using the data set for the season 2009 getting a good yield agreement of $R^{2}=0.95$ with $R M S E=0.21$ for $20 \mathrm{~cm}$ spacing and $R^{2}=0.93$ with $R M S E=0.4$ for $30 \mathrm{~cm}$ spacing. The calibrated model is validated using the data set for the season 2010, the agreement of $R^{2}$ equal to 0.88 with $R M S E=0.41$ for 20 cm spacing and $R^{2}=0.93$ with $R M S E=0.43$ yield for $30 \mathrm{~cm}$ spacing. The model is validated also for another place near Baghdad (Ishaqi) using experimental data for the season 2005, was obtained a good agreement of $\mathbf{R}^{2}=0.94$ between simulated and observed yield. A crop production functions were predicted for sunflower with $R^{2}=0.95$ for yield and 0.96 for biomass which could be a valuable term in irrigation management and decision making models.
\end{abstract}

KEYWORDS: AquaCrop, production function, sunflower yield

\section{INTRODUCTION}

Iraq has a semi-arid climate, and facing big challenges due to limited sources of water, where rainfall is less than the crop water requirement for economic production.

Sunflower is a summer oil crop, it is grown in Iraq under irrigation, and cultivated first in Iraq since the last century .Sunflower sowing date range at medium to last spring,seeding depth is around $5 \mathrm{~cm}$,plant density between 45000-60000 plant/ ha. Sunflower yields vary between less than 0.5 tons/ha to over 5 ton/ha (Steduto et al., 2012).

It is laborious and expensive to examine and test the effect of different water managements on yield production so simulation and modeling is a good tool to study the effect of different changes on any

system which represents here the effect of water application on yield. (Heidariniya et al., 2012).

FAO Irrigation and Drainage Paper 33 gave the relation between yield and irrigation which is recently developed to FAO AquaCrop model.
Main inputs to the model represents climatic data, crop, soil, irrigation and field management, the model simulate soil water balance, canopy cover, yield and biomass production (Raes et al., 2011), (Jin, Xiu-liang et al.,2014).

Irrigation experiment for summer maize was conducted during the years (2009-2010) in North China. The experimental results in 2010 were used to calibrate the crop parameters, and the other was used to validate the model. The results showed that the AquaCrop model could be reliably used to simulate soil moisture, dynamic changes of canopy cover, yield and biomass of summer maize. The relative error of simulated yield and biomass is $0 \%-15.6 \%$. For simulated the process of canopy cover and soil moisture, the minimum correlation coefficient of determination were $0.657,0.959$, the maximum of RMSE were $5.837 \%, 1.873 \mathrm{~m}^{3} / \mathrm{m}^{3}$ and the minimum model efficiency was $0.670,0.956$ respectively (Huil et al., 2011).

Parameterization and evaluation of AquaCrop model for Chinese green onion was done during 2009. The test was hold in North China Plain 
using soil water data, and yield data, and treatments with heavy Nitrogen application. The results showed that AquaCrop model simulated accurately the soil water storage and biomass without water stress condition. The RMSE between the simulated soil water storage values and measurements was $19.4-24.9 \mathrm{~mm}$, the relative error 3.9\%-12.4\%. The RMSE between the simulated biomass values and measurements was $0.31-0.73 \mathrm{t} / \mathrm{h}$, the relative error $5.8 \%-12.8 \%(\mathrm{Zi}-$ zhong et al., 2011).

Three field experiments were conducted in Ahvaz during three different seasons to study the ability of AquaCrop model to simulate wheat activity under full and deficit irrigation in south of Iran. The results showed a good agreement between observed and simulated data for yield, biomass, and soil water content (Andarzain et al., 2011).

(Todorovic et al., 2009) simulated sunflower growth under different water regimes at south Italy. They calibrated theAquaCrop model with experiment data in 2007 under full irrigation and validated with the model in 2005, then compared their work with other models CropSyst, and WOFOST which need more data but give approximate results. So it is better to use the AquaCrop model which is simple and needs less data.

(Garcia-Vila et al., 2009) used the AquaCrop model to predict yield response to water for cotton in southern Spain by applying irrigation water from $100 \mathrm{~mm}$ to $600 \mathrm{~mm}$ in $50 \mathrm{~mm}$ increase. They used four experimental data in two location to calibrate and validate the model.

AquaCrop model was evaluated according to yield, biomass production and water productivity of wheat crop data from different years and three different regions in Nineveh governorate in northern part of Iraq, Aljazerra project, HamamAlalel, and Telkeef regions using rainfed and supplementary irrigation. (Al-kaisy et al., 2011) found that there was a good agreement between the obtained yield, biomass and water productivity values from experiments and those predicted by AquaCrop model, The results obtained from the application of the model for HamamAlalel region in terms of wheat growth gave $95 \%$ agreement with the experimental data depending on $\mathrm{R}^{2}$ as a measure of agreement for rain fed wheat. Also there was a good correlation between simulated and observed water productivity of grain yield in Aljazerra project under rainfed irrigation and supplementary $\mathrm{R}^{2}$ are 0.6 and 0.95 respectively. The same conclusions can be drawn for the other region.

A field experiment was conducted in Rabi season of 2016-17 in India, to evaluate the AquaCrop model for Rabimaize at different levels of irrigation. The irrigation treatments consisted of all possible combinations of full irrigation or limited irrigation in such that $\mathrm{T} 1$ (full/control irrigation), T2 (75\% of CI), T3 (50\% of CI) and T4 (rainfed / no irrigation). The AquaCrop model evaluated for grain yield and biomass under different irrigation levels resulted in prediction error ranging from $2.25 \%$ to $9.59 \%$ and $2.44 \%$ to $11.84 \%$ respectively.The AquaCrop model was more accurate in predicting the Rabimaize yield under full and $75 \%$ of $\mathrm{CI}$ as compared to the rainfed and 50\% $\mathrm{CI}$ (Kumar et al., 2018).

The objectives of this study are to calibrate and validate the AquaCrop model for simulating sunflower production, using experimental data, and to predict the crop production function for sunflower.

\section{Model Descriptions}

The AquaCrop model is a crop growth model which combines four sub-models: the soil water balance; the crop development, growth and yield; the atmosphere sub-model, (reference evapotranspiration, ETo) and $\mathrm{CO} 2$ concentration; and the management sub-model, which includes irrigation and fertilization (Raes et al., 2011). The model is derived from FAO Paper No.33, according to the following equation, relating yield to the consumed water:

$$
\left(1-\frac{\mathrm{ya}}{\mathrm{y}_{\max }}\right)=\mathrm{K}_{\mathrm{Y}}\left(1-\frac{\mathrm{ET}_{\mathrm{a}}}{\mathrm{ET}_{\max }}\right)
$$

Where $Y_{\max }$ and $Y_{a}$ are the maximum and actual yield, $\mathrm{ET}_{\max }$ and $\mathrm{ET}_{\mathrm{a}}$ are the maximum and actual Evapotranspiration, and $\mathrm{K}_{\mathrm{Y}}$ is a coefficient which relate relative yield loss and relative reduction in Evapotranspiration.

Aqua Cropseparates evapotranspiration ET into crop Transpiration (Tr) and soil evaporation (E). Evaporation confused effect of nonproductive consumptive use of water during early stages when the ground cover is incomplete. Water is the main conductor of AquaCrop.(Heidariniya et al. 2012, Andarzian et al., 2011).Fig.(1) Chart of AquaCrop indicating the main components of the soil-plant-atmosphere continuum and the 
parameters driving phonology, canopy cover, transpiration, biomass production, and final yield.

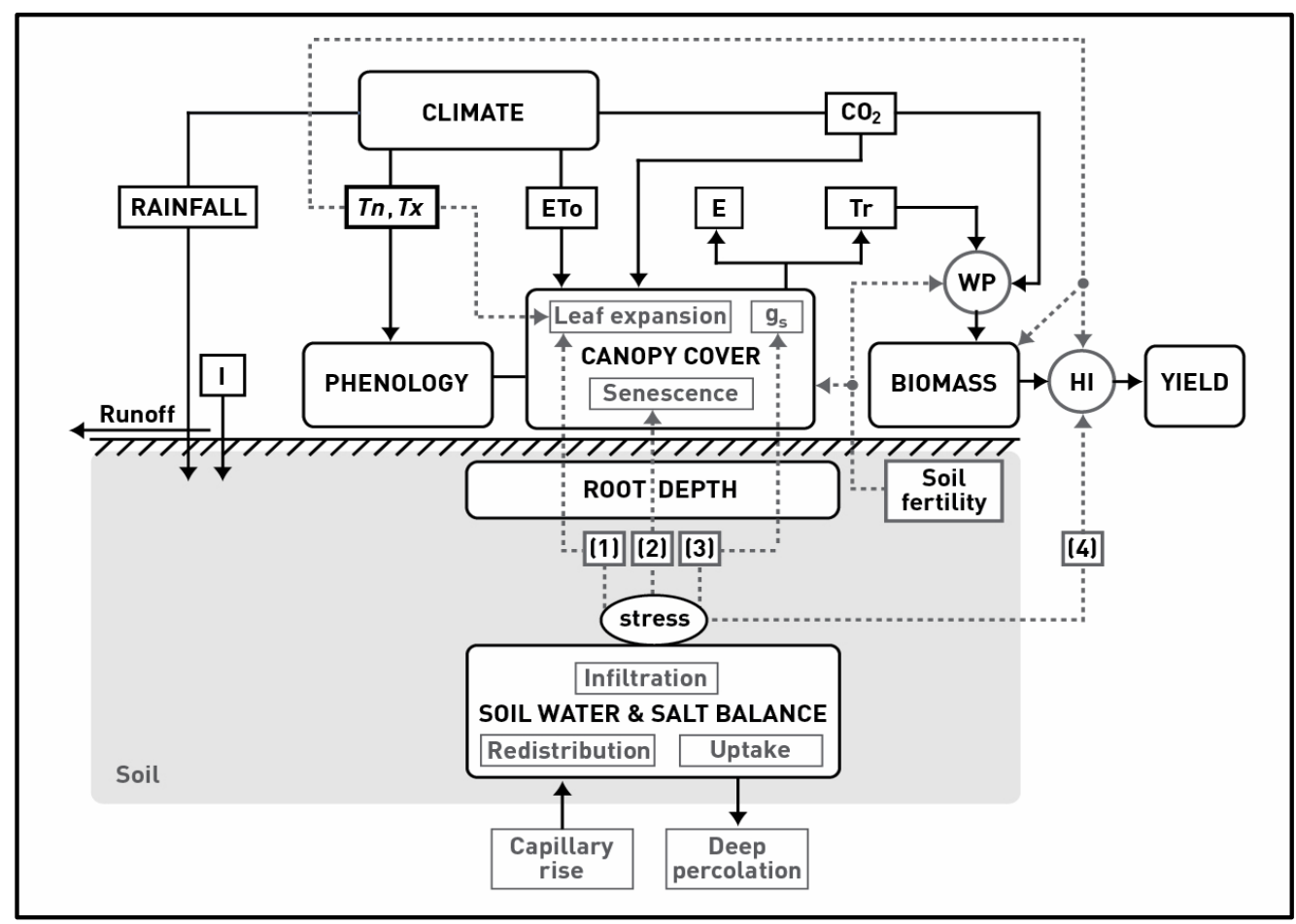

Fig.(1): Chart of AquaCrop indicating the main components of the soil-plant-atmosphere continuum.

[I, irrigation; Tn, minimum air temperature; Tx, maximum air temperature; ETo, reference evapotranspiration;E, soil evaporation; $\mathrm{Tr}$, canopy transpiration; gs, stomatal conductance; WP, water productivity; $\mathrm{HI}$, harvest index; $\mathrm{CO} 2$, atmospheric carbon dioxide concentration;(1), (2), (3), (4), water stress response functions for leaf expansion, senescence, stomatal conductance and harvest index, respectively]. Continuous lines indicate direct links between variables and processes. Dashed lines indicate feedbacks (Raes et al. 2018).2. MATERIALS AND

METHODS//I/ Sunflower yield for two seasons under different irrigation management practices were chosen to test the AquaCrop model using data sets of field experiments at Abu-Graib, Baghdad.

Field experiments with three replications was conducted during the summer seasons 2009 and 2010 at the college of agriculture, University of
Baghdad. All experiments include one Sunflower cultivar that were sowed within spacing $20 \mathrm{~cm}$ and $30 \mathrm{~cm}$. Control treatment (full irrigation $\left(\mathrm{S}_{1}\right)$, a depletion of $50 \%$ of available water) and three other treatments $\mathrm{S}_{2}, \mathrm{~S}_{3}, \mathrm{~S}_{4}$ which represented $75 \%$, $50 \%$ and $25 \%$ of the water amount of control with two row spacing 20 and $30 \mathrm{~cm}$ (Ahmed, 2012).

Validation of AquaCrop model is tested for another place using experimental data for sunflower cultivated at Ishaqi near Baghdad for the season 2005(Ali and Abbas, 2008).

\section{Climatic data and soil properties}

Climate data for the experiment location at Abu-Graib Baghdad at latitude $33.23 \mathrm{~N}$, longitude $44.23 \mathrm{E}$ and an altitude of $34 \mathrm{~m}$ above sea level. Potential evapotranspiration was calculated using Penman Monteith equation. Climatic data and soil properties were shown in tables $(1,2,3)$ and 
Table (1):Climatic data for experimental locations Abu Graib 2009 (Ahmed, 2012).

\begin{tabular}{cccccccc}
\hline Month & \multicolumn{3}{c}{ Temperature } & $\begin{array}{c}\text { Rain } \\
\mathrm{mm}\end{array}$ & $\mathrm{RH} \%$ & $\begin{array}{c}\text { Wind } \\
\text { speed } \\
\text { m/ser }\end{array}$ & $\begin{array}{c}\mathrm{RS} \\
\mathrm{MJ} / \mathrm{m} 2 / \text { day }\end{array}$ \\
\cline { 2 - 5 } March & Max. & Min. & mean & & & 3.60 & 18.40 \\
\hline April & 32.90 & 12.00 & 18.50 & 11.90 & 25.80 & 3.60 & 22.60 \\
\hline May & 39.70 & 24.30 & 32.00 & 0 & 15.60 & 3.60 & 25.60 \\
\hline June & 46.10 & 29.80 & 38.00 & 0 & 11.80 & 4.00 & 27.80 \\
\hline
\end{tabular}

Table (2): Climatic data for experimental locations Abu Graib 2010.

\begin{tabular}{|c|c|c|c|c|c|c|c|}
\hline \multirow[t]{2}{*}{ Month } & \multicolumn{3}{|c|}{ Temperature } & \multirow{2}{*}{$\begin{array}{l}\text { Rain } \\
\text { mm }\end{array}$} & \multirow[t]{2}{*}{$\mathrm{RH} \%$} & \multirow{2}{*}{$\begin{array}{l}\text { Wind } \\
\text { speed }\end{array}$} & \multirow{2}{*}{$\begin{array}{c}\mathrm{RS} \\
\mathrm{MJ} / \mathrm{m} 2 / \text { day }\end{array}$} \\
\hline & Max. & Min. & mean & & & & \\
\hline March & 28.80 & 14.90 & 21.90 & 12.00 & 32.20 & 3.60 & 17.64 \\
\hline April & 34.00 & 19.70 & 26.90 & 10.60 & 26.20 & 3.40 & 22.00 \\
\hline May & 40.60 & 25.20 & 32.90 & 0 & 19.30 & 3.90 & 26.50 \\
\hline June & 46.10 & 30.40 & 38.30 & 0 & 13.30 & 4.40 & 28.10 \\
\hline
\end{tabular}

Table (3): climatic data for experimental locationsIshaqi 2005.

\begin{tabular}{|c|c|c|c|c|c|c|c|}
\hline \multirow[t]{2}{*}{ Month } & \multicolumn{3}{|c|}{ Temperature } & \multirow{2}{*}{$\begin{array}{l}\text { Rain } \\
\text { mm }\end{array}$} & \multirow[t]{2}{*}{$\mathrm{RH} \%$} & \multirow{2}{*}{$\begin{array}{l}\text { Wind } \\
\text { speed }\end{array}$} & \multirow{2}{*}{$\begin{array}{c}\mathrm{RS} \mathrm{MJ} / \mathrm{m} 2 / \text { day } \\
\cdot\end{array}$} \\
\hline & Max. & Min. & mean & & & & \\
\hline March & 22.40 & 10.00 & 16.20 & 12.10 & 38.10 & 4.20 & 17.30 \\
\hline April & 31.20 & 15.00 & 23.10 & 10.30 & 29.90 & 4.30 & 20.50 \\
\hline May & 38.20 & 20.00 & 29.10 & 0 & 22.30 & 4.50 & 23.40 \\
\hline June & 44.80 & 23.00 & 33.90 & 0 & 17.20 & 4.90 & 26.30 \\
\hline
\end{tabular}

Table (4): Soil properties (Israelsen and Hansen, 1962) and (Ali and Abbas, 2008).

\begin{tabular}{ccc}
\hline property & Abu-Graib & Ishaqi \\
\hline Soil texture & Silty clay Loam & Silt loam \\
\hline Field capacity\% vol. & 35.00 & 29.00 \\
\hline Permanent wilting point\% & 15.00 & 13.00 \\
\hline Saturation\% & 51.00 & 46.00 \\
\hline TAW & 200.00 & 160.00 \\
\hline Ksatmm/day & 100.00 & 150.00 \\
\hline
\end{tabular}

\section{CALIBRATION AND VALIDATION OF AQUACROP}

There are two groups of parameters in AquaCrop model. One group that remain constant under different growing condition and water, it is conservative, and the other group that are dependent on location, crop cultivar and management practice and must be specified by the user. One experiment for the season $2009,20 \mathrm{~cm}$ row spacing with different management condition was used for AquaCrop calibration, while data sets for the season 2010, Abu Graib and Ishaqi were used for AquaCrop validation. Tables $(5,6)$ show the parameters used in the model.Water use 
efficiency (WUE) also used in calibration and validation of AquaCrop model. (WUE) is defined as the grain yield per unit amount of water consumed.(Khoshravesh et al., 2012).

Table (5): conservative parameters used for sunflower calibration and validation of the AquaCrop model.

\begin{tabular}{ll}
\hline Parameter & Value \\
\hline Base temperature & 10 celsius \\
\hline upper temperature & 30.00 \\
\hline Reference harvest index & $50.00 \%$ \\
\hline Canopy size of the average seedling at 90 percent emergence (cco) & 0.25 \\
\hline Canopy growth coefficient (CGC) & $14.50 \%$ \\
\hline Canopy decline coefficient (CDC) & $8.00 \%$ \\
\hline Water productivity normalized for ETo and CO2 (WP*) & $17 \mathrm{gm} / \mathrm{m}^{2}$ \\
\hline Leaf growth threshold p-upper & 0.25 \\
\hline Leaf growth threshold p- lower & 0.55 \\
\hline Stomatal conductance threshold p- upper & 0.50 \\
\hline Senescense stress coefficient curve shape & 0.85 \\
\hline Senescense shape factor & 3.00 \\
\hline
\end{tabular}

Table (6): some of user-specific parameters used for sunflower calibration and validation of the AquaCrop model.

\begin{tabular}{cccc}
\hline Parameter description & $\begin{array}{c}\text { Abu Graib } \\
\mathbf{( 2 0 0 9 )}\end{array}$ & $\begin{array}{c}\text { Abu Graib } \\
\mathbf{( 2 0 1 0 )}\end{array}$ & $\begin{array}{c}\text { Ishaqi } \\
\mathbf{( 2 0 0 5 )}\end{array}$ \\
\hline $\begin{array}{c}\text { Plant density plant/ha } \\
\text { Length building up harvesting index } \\
(\text { HU) (dav) }\end{array}$ & 60000.00 & 60000.00 & 53333.00 \\
\hline $\begin{array}{c}\text { Maximum rooting depth( } \mathrm{m}) \\
\text { Time to maximum rooting depth, } \\
\text { calendar davs }\end{array}$ & 46.00 & 60.00 & 46.00 \\
\hline $\begin{array}{c}\text { To emergence } \\
\text { To max. canopy cover }\end{array}$ & 60.00 & 60.00 & 60.00 \\
\hline To start of canopy senescence & 6.00 & 10.00 & 6.00 \\
\hline To maturity & 50.00 & 50.00 & 50.00 \\
\hline To flowering & 93.00 & 93.00 & 93.00 \\
\hline Duration of flowering & 112.00 & 122.00 & 112.00 \\
\hline
\end{tabular}




\section{DATA ANALYSIS}

Statistical methods were used to evaluate AquaCrop model by comparing yield data, and water used efficiency(WUE), derived from experiment and output of the model simulations. Root Mean Square Error(RMSE), Coefficient of Mass Residual (CRM),Model Efficiency(EF)(Helmerset al., 2006), (Zhang et al., 2013).

$$
\begin{aligned}
& \text { RMSE }=\sqrt{\sum_{\mathrm{i}=1}^{\mathrm{n}}\left(\frac{(\mathrm{Si}-\mathrm{Oi})^{2}}{\mathrm{n}}\right) \ldots \ldots .} \\
& \mathrm{CRM}=\frac{\sum_{i=1}^{n}(\mathrm{Oi})-\sum_{i=1}^{n}(\mathrm{Si})}{\sum_{i=1}^{n}(\mathrm{Oi})} \ldots \ldots \ldots \\
& \mathrm{EF}=1-\frac{\sum_{i=1}^{n}(\mathrm{Si}-\mathrm{Oi})^{2}}{\sum_{i=1}^{n}\left(\mathrm{O}_{\mathrm{i}}-\mathrm{O}^{-}\right)^{2}} \ldots \ldots \ldots . .
\end{aligned}
$$

Where $\mathrm{S}_{\mathrm{i}}$ and $\mathrm{O}_{\mathrm{i}}$ are the simulated and observed (measured) values respectively, $\mathrm{n}$ is the number of observation. $\mathrm{S}^{-}$, and $\mathrm{O}^{-}$average values of the simulated and measured data. Unit of RMSE is the same for both variables, and the model's fit improves as RMSE tends toward zero. (Stricevic et al., 2011).A positive value for CRM indicates a tendency of under estimation, while a negative value indicates a tendency of overestimation Model efficiency EF can range

\section{RESULTS AND DISCUSSION}

The results show that the model performed well for simulating yield and water use efficiency. As shown in table $(\vee)$, there were generally good agreement between the model prediction and measured yield and water use efficiency WUE.The observed yield for ( $\mathrm{S}_{1}$ treatment) varied from $2.9 \mathrm{t} / \mathrm{ha}$ to $3.82 \mathrm{t} / \mathrm{ha}$, while the simulated yield varied from $3.59 \mathrm{t} / \mathrm{ha}$ to $3.671 \mathrm{t} / \mathrm{ha}$.

The values of $\mathrm{R}^{2}$ for grain yield varied from 0.88 to 0.95 , RMSE varied from 0.21 to $0.48 \mathrm{t} / \mathrm{ha}$, and $\mathrm{R}^{2}$ for WUE varied from 0.59 to 0.99 , RMSE varied from 0.085 to $0.12 \mathrm{t} / \mathrm{ha}$.It appears from CRM values that observed and predicted yield from $-\infty$ to $1 .(E F=1)$ corresponds to a perfect match of simulated to the observed data. An efficiency of $0(\mathrm{EF}=0)$ indicates that the model predictions are as accurate as the mean of the observed data, whereas an efficiency less than zero occurs when the observed mean is a better predictor than the model.

\section{Simulating yield response to irrigation water}

After model calibration and validation, the model was used to determine yield response to variable irrigation depth. The irrigation method used in the simulation was furrow. To determine yield response to water, simulations were performed starting with $150 \mathrm{~mm}$ to $570 \mathrm{~mm}$ of seasonal available irrigation water(AIW). At each level of (AIW) the AquaCrop was run many times by changing the timing of the total irrigation along the season to match max. yield. Three to four irrigations were applied, at initial, vegetation, flowering, or/and maturity.

Then yield response factor $\left(\mathrm{K}_{\mathrm{y}}\right)$ was estimated by plotting a relation between relative yield loss $\left(1-\frac{y_{a}}{y_{\max }}\right)$ andrelative reduction in evapotranspiration $\left(1-\frac{\mathrm{ET}_{\mathrm{a}}}{\mathrm{ET}_{\max }}\right)$ for the total growing period for various values of seasonal yield(Geneille et al.,2017).

and WUE for different irrigation management conditions with two row spacing and two seasons are over -or underestimated. At AquaCrop calibration, model efficiency (EF) for grain yield and WUE are0.88 and 0.86 respectively, and during model validation $\mathrm{EF}$ are 0.5 and 0.98 respectively.

The observed and predicted yield and WUE for different irrigation management conditions with two row spacing and two seasons are given in Fig (2) \& Fig (3). There is a closer match between simulated and observed yield and WUE throughout all treatments with $20 \mathrm{~cm}$ and $30 \mathrm{~cm}$ row spacing. The model performed satisfactory during the validation period. 
Table ( $\vee$ ): Statistical analysis for evaluating the performance of the AquaCrop model in predicting yield and WUE of sunflower.

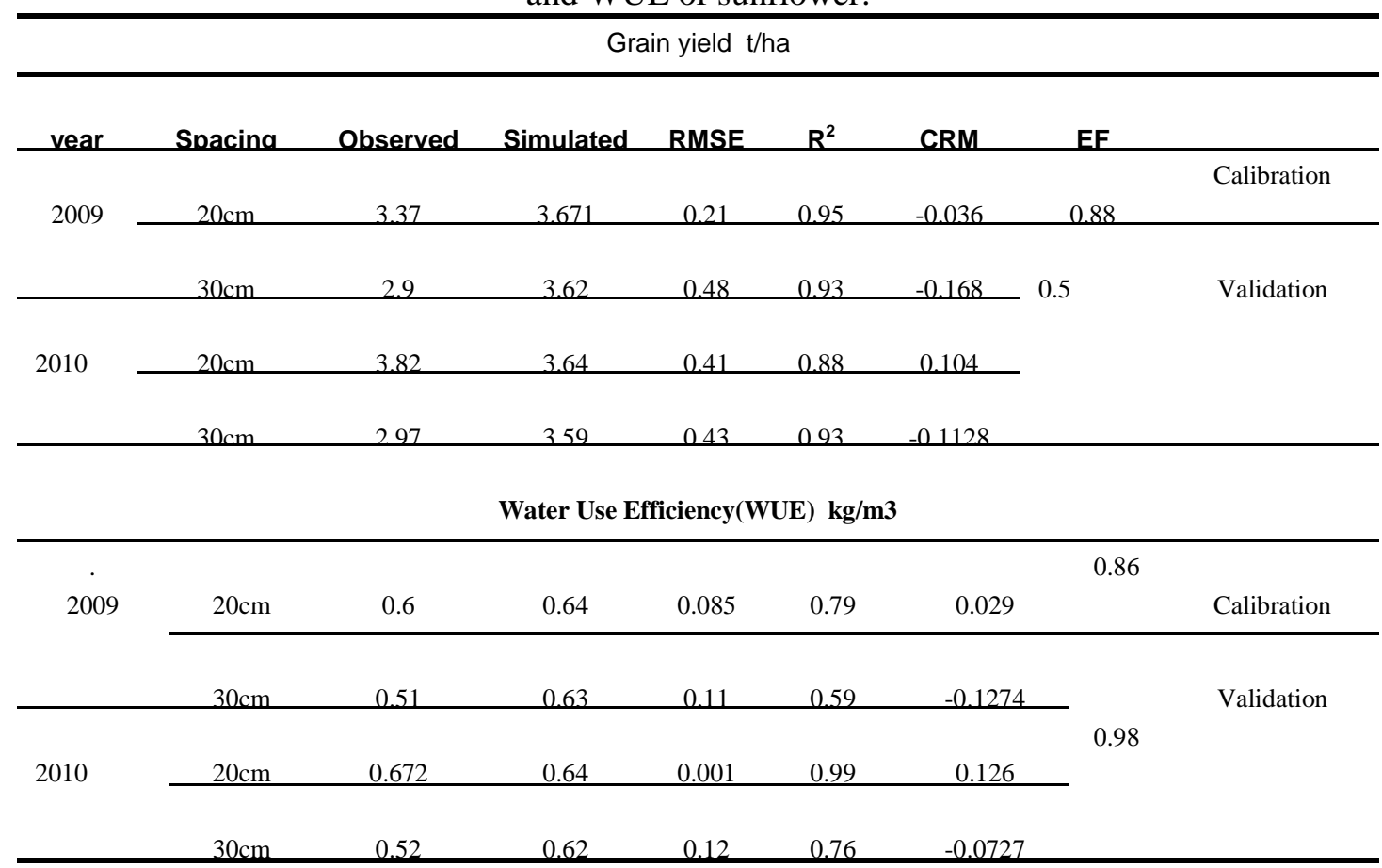

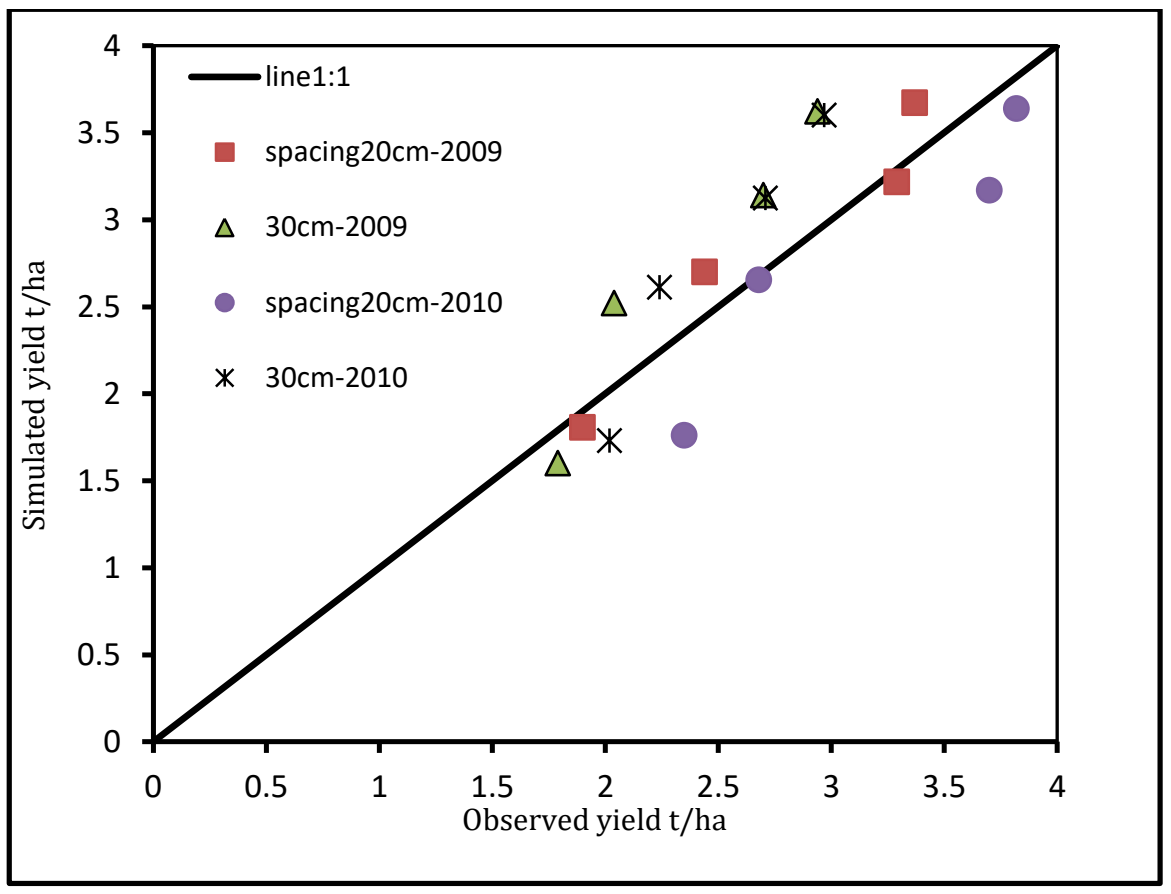

Fig. (2):Simulated versus observed grain yield for Abu-Graib. 


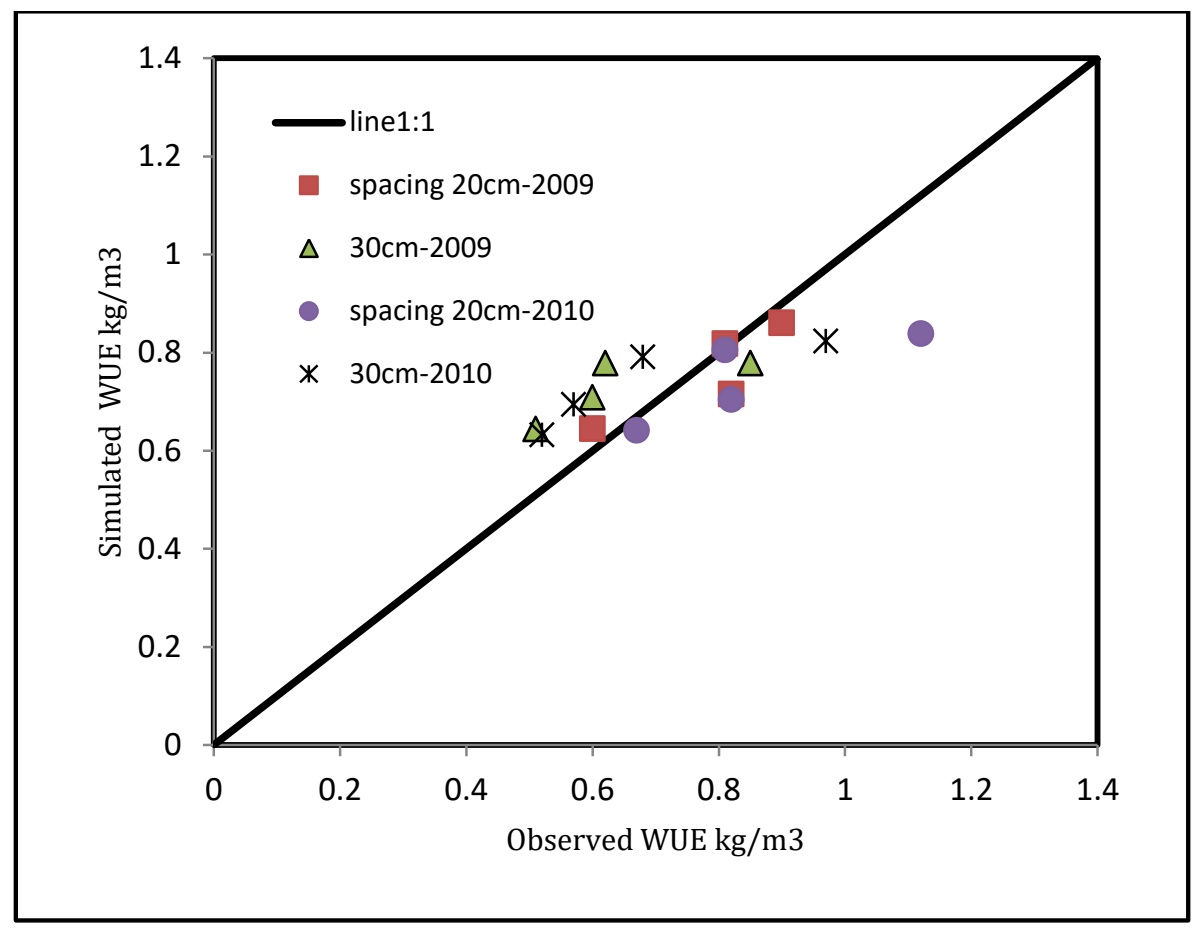

Fig. (3): Simulated versus observed wue for Abu-Graib.

Another validation with place was done between Abu Graib and Ishaqi near Baghdad as shown in Fig.(4). Calibration equation was determined with linear regression between observed (measured) and simulated yield ofAbu Graib, $\mathrm{y}=0.853 \mathrm{x}+0.3197$, with $\mathrm{R}^{2}=0.9374$ where $\mathrm{y}=$ observed yield, $\mathrm{x}=$ simulated yield. Then validation was tested by inserting simulated values from Ishaqi in the calibration equation.

With regard to the results of calibration and validation, it could be concluded that AquaCrop model satisfactory simulates grain yield for different management conditions of the sunflower crop in middle of Iraq.

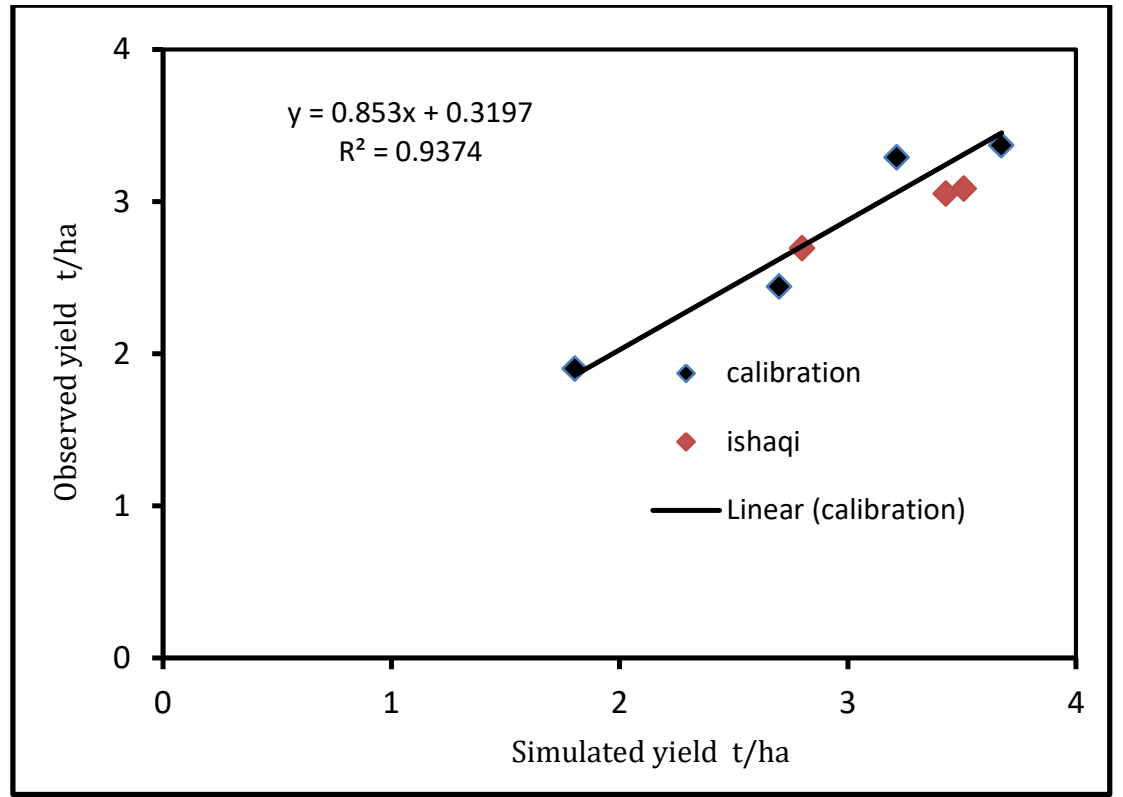

Fig. (4): Observed versus simulated yield of Abu-Graib and Ishaqi. 


\section{Model application:}

After model validation, the model was used to evaluate the effect of different irrigation depths on crop yield and biomass. Fig (5) show the max yield and biomass obtained at each irrigation starting from $150 \mathrm{~mm}$ to $570 \mathrm{~mm}$ of water, the water production function for yield and biomass was obtained as shown in Fig (5) where y=yield or biomass, $\mathrm{x}=$ depth of irrigation water with $\mathrm{R}^{2}$ $=0.95$ for yield and $\mathrm{R}^{2}=0.96$ for biomass, these functions are highly needed in water decision models.
Fig. (6) shows relation between relative yield loss and relative reduction in evapotranspiration, the crop response factor $\left(\mathrm{K}_{\mathrm{y}}\right)$ is the slope of the regression line after forcing the line to pass through the origin. As $\mathrm{K}_{\mathrm{y}}$ is less than (1) for different irrigation management conditions with two row spacing and two seasons, it could be concluded that sunflower is drought resistance, and can be included in strategies of controlled deficit

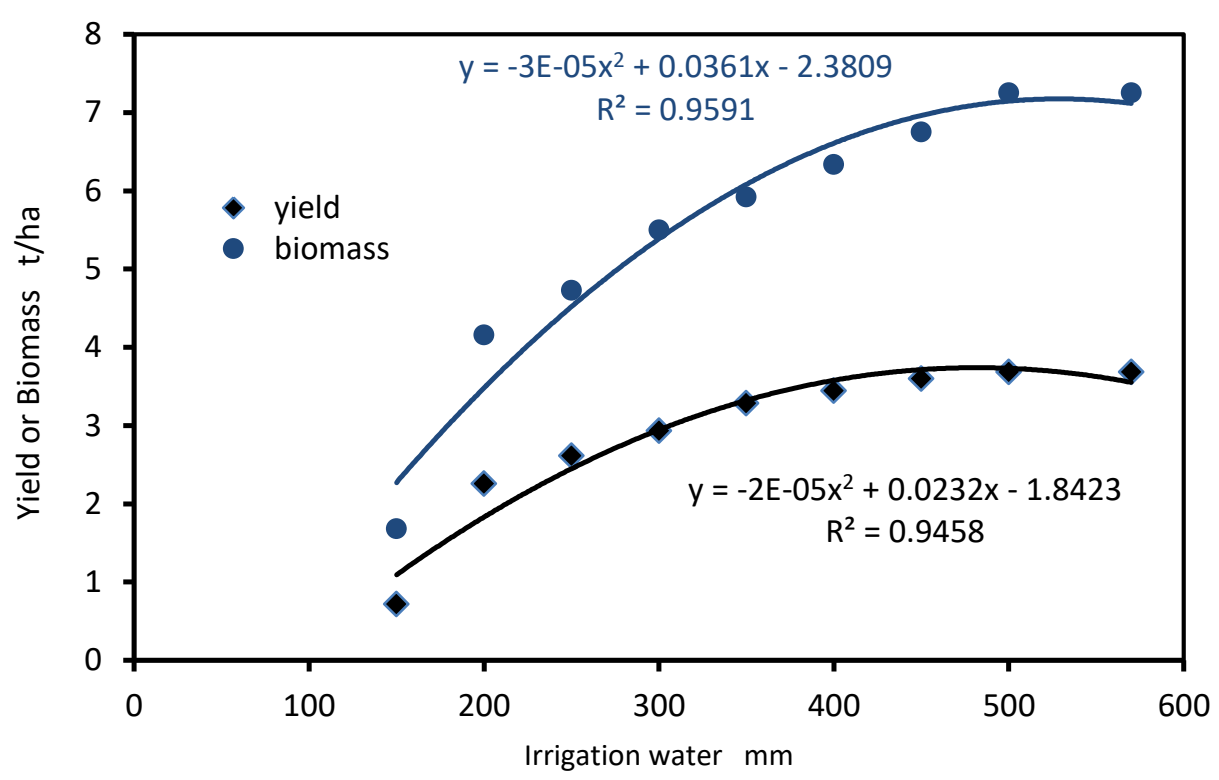

Fig. (5): Yield and Biomass versus irrigation water. 


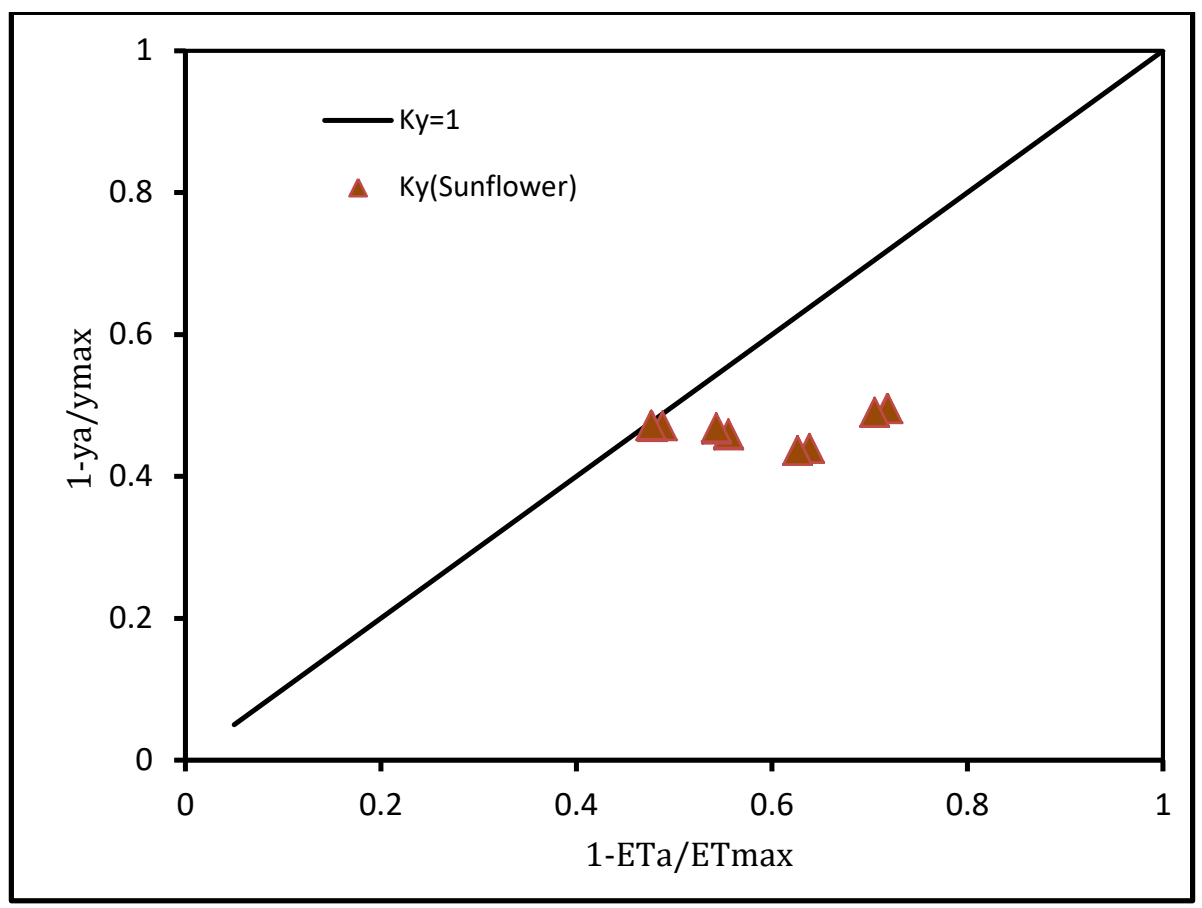

Fig. (6): Estimation of crop response factor $\mathrm{K}_{\mathrm{y}}$.

\section{REFERENCES}

-Ahmed, Sh. A. (2012)."Effect of water stress and hill spacing on seed yield and some growth traits of Sunflower ".The Iraqi Journal of Agricultural Sciences 43 (4): 14-27.

-Ali, M. M. and Abbas, A. A. (2008). " Effect of irrigation intervals and potassium fertilization on growth and yield of Sunflower Helianthus annunsL". The Jordian Journal for Agricultural Sciences. Vol. 4, No. 2. 207-216.

-Al-kaisy , E. M., Alani, E. A., Abid, M. M. (2011)."Using AquaCrop model for supplementary and rain fed irrigation in North Iraq". ICID 21st International Congress on Irrigation. and Drainage, 15-23 October 2011, Tehran, Iran.

-Andarzian, B., Bannayan, M., Steduto, P., Mazraeh, H. Barati, M.E., Barati, M.A., Rahnama, A. (2011)."Validation and testing of theAquaCrop model under full and deficit irrigated wheat production in Iran".Agricultural Water Management, (100), 1-8.

-García-Vila, M., Fereres, E., Mateos, L. Orgaz, F., and Steduto, P. (2009). "Deficit irrigation optimization of Cotton with AquaCrop". Agronomy Journal • Volume 101, Issue 3.

-Geneille E. Greaves and Yu-Min Wang.(2017)." Yield response, water productivity, and seasonal water production functions for maize under deficit irrigation water management in southern
Taiwan". Plant Production Science, Vol. . 20, no. 4, 353-365.

-Helmers, Qi, Z., M, and Singh, R.( 2006). "Evaluating a drainage model using soil Hydraulic parameters derived from various methods". Conference Proceeding, ASABE Annual International Meeting ASAE Meeting Paper No. 062318. St. Joseph, Mich. :ASAE.

- Heidariniya, M., Naseri, A.A., Boroumandnasab, S., Moshkabadi, B.S., Nasrolahi, A.H. (2012)." Evalution of AquaCrop model application in irrigation management of Cotton ". World Rural Observations; 4(2). http://www.sciencepub.net/rural.

-Hui1, Li. Liu Yu, CaiJia-bing,Mao Xiao-min.(2011). The applicability and application of AquaCropmodel"..Journal of Irrigation and Drainage .2011-3.

-Israelsen, O. W. and Hansen, V. E., (1962). Irrigation Principles and Practices. Wiley International Edition, $447 \mathrm{P}$.

-Jin, Xiu-liang, Hai-kuanFeng, Xin-kai Zhu, Zhen-hai Li, Sen-nan Song, Xiao-yu Song, Gui-jun Yang, Xin-gang $\mathrm{Xu}$, and Wen-shanGuo (2014). "Assessment of the AquaCropmodel for usein simulation of irrigated winter wheat canopy cover, biomass, and grain yield in the North China plain", PLOS ONE.

-Khoshravesh, M.,Mostafazadeh-Fard, B., Heidarpour, M.and Ali-Reza K..(2012). "AquaCrop 
modelsimulation under different irrigation water andnitrogen strategies".Water Science \&Technolog.

-Kumar, V., Chandra, R. and Jain, SK .(2018.)" Performance evaluation of AquaCrop Model for Rabi Maize crop in theNorth Bihar condition". Journal of Pharmacognosy and Phytochemistry, 7(5): 973-979.

-Raes D, Steduto, P., Hsiao CT, Fereres, E.(2011) . FAO crop water productivity model to simulate yield response to water", (A):-Reference Manual, AquaCrop Version 3.1 plus.

-Raes D, Steduto, P., Hsiao CT, Fereres, E. (2018).Reference Manual, AquaCrop, Version $6.0-6.1$.

-Steduto, P, Theodore C. Hsiao, Fereres, E. and Raes, D. (2012) . Crop yield response to water.FAO Irrigation and Drainage PapperNo. 66. Rome. Italy.
-Stricevic, R., N.Djurovic, M. Cosic3 and B. Pejic.(2011). "Assessment of the AquaCropmodel in simulating rainfed and supplementallyirrigated sweet Sorghum growth".ICID 21st International Congress on Irrigation and Drainage 15-23 October 2011, Tehran, Iran.

- Zhang, W., Wenzhao L., QingwuXue,JieChen, and Xiaoyang, H.(2013)." Evaluation ofthe AquaCrop model for simulating yieldresponse of winter wheat to water on thesouthern Loess Plateau of China".WaterScience\& Technology, 2013.

-Zi-zhong, LI., XU Yang,LU Xian-ju,HUKe-lin,JIANG Li-hua,XU Yu. (2011). "Evaluation of the AquaCrop model for simulating biomass for Chinese green onion and soil water storage". Journal of China Agricultural University, 4.

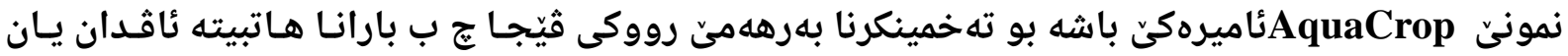

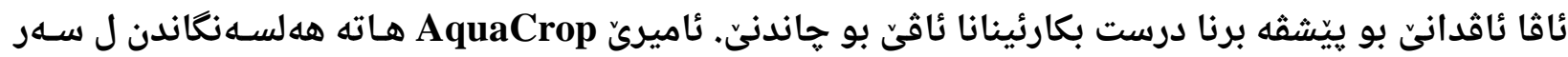

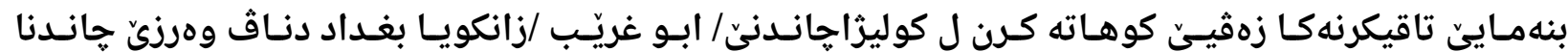

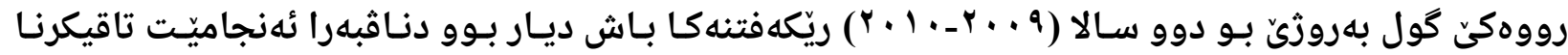

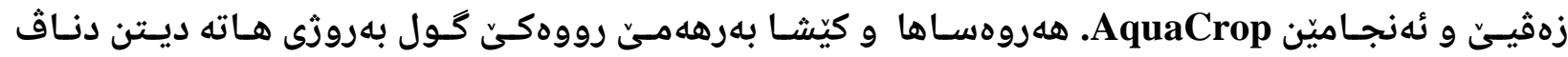

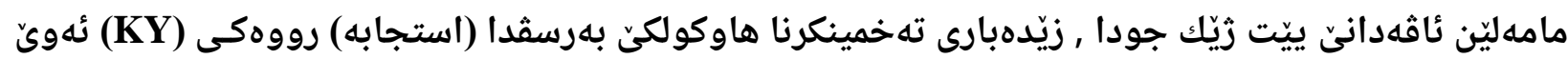

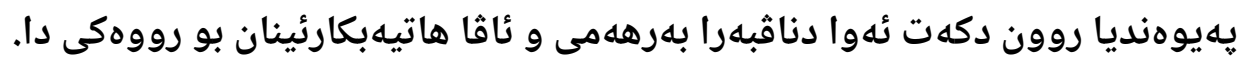

نموذج AquaCrop اداة جيدة لتخمين انتاجية المحصول سواء كان بالأمطار أو بالري لتطوير كفاءة أستخدام المياه في الزراعة. تم تقييم اداء AquaCrop اعتمادا على تجربة حقلية اجريت في كلية الزراعة/ ابو غريب/

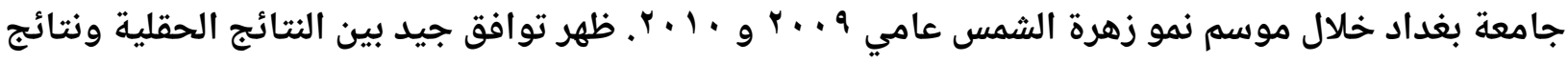
AquaCrop معامل استجابة المحصول ky الذي يوضح العلاقة بين الانتاجية والماء المستخدم للمحصول. 